\title{
11. Pacific freedom of the press: Case studies in independent campus-based media models
}

\section{ABSTIRACII}

South Pacific university-based journalism school publications were innovative newspaper publishers from 1975 onwards and among early pioneers of online publishing in the mid-1990s. Several publications have become established long-term with viable economic models and have had an impact on Oceania's regional independent publishing. All have been advocates of a free press and freedom of expression under Article 19 of the Universal Declaration of Human Rights. Among early trendsetters were Uni Tavur, Liklik Diwai in Papua New Guinea, and Wansolwara and Pacific Journalism Online in Fiji. Wansolwara and its online edition was also the flagbearer for independent publishing under the pressure of two coups d'état in 2000 and 2006 in Fiji. All newspapers have contended with censorship in various forms. Now Wansolwara has embarked on a publishing partnership with a leading post-coup Fiji daily newspaper. This article analyses the independent media published by communication studies educational programmes in Fiji and Papua New Guinea. It examines how a variety of niche publishing formula have boosted independent coverage and issues-based journalism on wide-ranging topics such as human rights, news media facing censorship and freedom of information.

Keywords: academic freedom, censorship, freedom of information, human rights, independent publishing, Uni Tavur, Wansolwara

\section{DAVID ROBIE}

Pacific Media Centre, AUT University

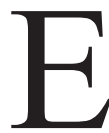

VERY national constitution in Oceania includes some reference to press freedom, even though it is perhaps breached more than honoured. It is often enshrined in documents, such as Article 19 of the Universal Declaration of Human Rights. South Pacific nations also take 
the annual observance of UNESCO World Press Freedom Day on May 3 rather more seriously than their southern neighbours, Australia and New Zealand. However, there is little agreement on the detail of what 'press freedom' actually means or much debate on balancing this right with other freedoms accepted as part of a modern democracy (Stevenson, 2004, p. 67). At times, there is also a perception in Pacific countries that media organisations have a self-interested view that has more to do with the freedom of the broadcasters and publishers rather than the basic rights of citizens to be informed (Robie, 2001a; 2008a; Singh \& Prasad, 2008).

The study of an independent student press and online or broadcast media in the Pacific has been neglected and rarely raised in any industry debate on media freedom (Robie, 2002). South Pacific university-based journalism school publications were innovative newspaper publishers from 1975 onwards and among early pioneers of online publishing in the mid-1990s. Several publications have become established long-term with viable economic models and have had an impact on Oceania's regional independent publishing. All have been advocates of a free press and freedom of expression under Article 19. Among early trendsetters were Uni Tavur and Liklik Diwai in Papua New Guinea, and Wansolwara and Pacific Journalism Online in Fiji. Wansolwara and its online edition was also the flagbearer for independent publishing under the pressure of two coups d'état in 2000 and 2006 in Fiji. All newspapers have contended with censorship in various forms. In 2009, Wansolwara embarked on a publishing partnership with a leading post-coup Fiji daily newspaper. This article analyses the independent media published by communication studies educational programmes through selected case studies in Fiji and Papua New Guinea. It examines how a variety of niche publishing formula have boosted independent coverage and issues-based journalism on wide-ranging topics such as human rights, news media facing censorship and freedom of information.

In the Pacific, I have had the privilege over a decade of teaching a remarkable diversity of students involved in the campus press, sometimes in the face of threats and risks. For example, in Papua New Guinea I taught the daughter of a former Defence Force Commander and the daughter of the then Chief Justice of PNG. In Fiji, I taught a police inspector and a captain charged with establishing a media unit in the military forces. One of my journalism graduates at USP also became one of the first two women drafted into the Fiji military and, unfortunately, she became one of the military officers at the forefront of Fiji censorship after the Easter putsch.

100 PACIFIC JOURNALISM REVIEW 16 (2) 2010 
The vast majority of student journalists have remained staunchly committed to a free press in the Pacific, often in the face of great adversity and hardship. Some are now in key positions in the news media around the Pacific, such as Gorethy Kenneth at the Buka office of the Post-Courier in Papua New Guinea; Stanley Simpson, news director at the Fiji Broadcasting Corporation; and Emily Moli, news editor at Fiji Television.

Covering the 2000 Fiji attempted coup and the three months of intensive trauma that followed has been the toughest call faced by the then sevenyear-old University of the South Pacific Journalism Programme and by me personally as a journalism educator. Many stories of courage emerged out of the events - the neophyte 'Indian' journalist who was kissed uninvited by rebel leader George Speight, the 'barefoot' journalists who slipped daily into Parliament by bushtrack, and the editing team who camped out in the newsroom, sometimes sleeping there to avoid curfew arrest.

In more than a decade in journalism education in the Pacific, I encountered many examples of threats to press freedom and student journalists responding courageously and with resilience. The case studies outlined here reflect this.

\section{Uni Tavur (Papua New Guinea)}

The University of Papua New Guinea's training publication Uni Tavur played an important role in the formation of journalists for more than two decades (Robie, 2004; 2008). Uni Tavur was launched on 24 July 1975 by New Zealand television journalist and media educator Ross Stevens. Tavur means 'conch shell' in the Tolai language of the Gazelle Peninsula, East New Britain. The shell was the paper's masthead logo. Journalism student Robert Elowo, who died tragically the following year in a car accident while working for the National Broadcasting Commission's Radio Kundiawa, designed the original version. Uni is derived from the university. The first newsroom was set up in 'the dungeon' - dubbed this by the students because of the claustrophobic bunker-style room used below the Michael Somare Library (cited in Robie, 2004, p. 128).

Uni Tavur's first edition carried news items, including social and sports events. It consisted of four A4-size pages and had a circulation of 200 copies. Student reporters were assigned rounds with a brief to cover anything of news value for their readers. Recalled former Vice-Chancellor Joseph Sukwianomb:

Uni Tavur came [...] to play a significant role in the university scene in terms of changing ideas [...] generally about that period from 
independence $[\ldots]$ the campus was very vibrant, very active. The students were well aware of what was happening. This was the time of student demonstrations and strikes. They were all reported from student angles by student journalists. (Cited in Robie, 2004, p. 129)

Over the following quarter century, Uni Tavur experienced many changes but persisted with a vigorous and gutsy reporting style: 'Whether it was life on campus, life on the borderline, the political scene or anything of national interest, the students sweated to get the paper going,' wrote first-year journalism student Jessie Waibauru in the 20th anniversary issue (1994, p. 10). Stories covered ranged from the West Papuan issue and border tensions with Indonesia, corruption and a draft law introduced in Parliament to gag the news media. It was later withdrawn (Robie, 2004, p. 238). In a retrospective survey of Uni Tavur, Waibauru captured the essence of a lively publication and a snapshot of post-independence history.

The newspaper marked two decades of publishing by being relaunched as a tabloid newspaper with some four-colour editorial and advertising content in 1995. Uni Tavur came of age by being printed as a half-reel on the PostCourier presses. The same year, it won the Journalism Education Association prize for the best regular publication - the first Pacific or New Zealand title to do so, in part because of a series of groundbreaking investigative journalism reports published by the paper. Two years later, Uni Tavur student journalists reported on the Sandline affair when the Sir Julius Chan government hired a mercenary company in an attempt to crush the Bougainville rebellion. This led to a revolt in the PNG Defence Force with troops ordered by commander Brigadier-General Jerry Singirok to arrest the mercenaries in Operation Rausim Kwik on the night of 16 March 1997. Chan was ultimately forced to resign. At the height of the crisis, the students at the University of Papua New Guinea boycotted classes in support of Singirok.

\section{The Topul Rali affair}

After surviving attempts to gag the newspaper by politicians, the following year witnessed Uni Tavur defending its independence from the university administration after publishing an exposé about a senior academic administrator implicated in a violent protest over the killing of anthropology lecturer on campus in December 1995 (Robie, 1998). The dead woman, Janet Kisau, was the second lecturer to be murdered at the university in less than 
seven months. Also, two students were murdered during 1995 during a security crisis at the university (Johnston, 1996). Protesters caused an estimated K10,000 worth of damage in an administration office, trashed a computer and an administration staff member was wounded.

Although the incident was hushed up by the administration, the incoming Vice-Chancellor Dr Rodney Hills, an Australian, instituted an inquiry into the raid in February 1996. In March, the University Council voted at an extraordinary meeting to dismiss Dr Topul Rali, one of the university's most prominent local academics who was widely regarded as a potential future vice-chancellor. He had been implicated in the administration protest and an open letter in The National alleged a news media cover-up of the scandal (The National, 23 February 1996).

Uni Tavur gathered information about the affair and published reports without fear or favour. These included a fullpage background article and front page story about the sacking of Dr Rali (Miise, 1996a, 1996b, 1996c). The university administration pressured the paper over the stories in an attempt to prevent publication but avoided doing so in public. News reports from the paper about the affair being filed to the regional news agency Pacnews were secretly removed from the university administration facsimile room and destroyed. The lecturer supervising the newspaper (along with two senior faculty members) was summoned to the vice-chancellor's office and the newspaper was accused of 'breach of confidence' and 'defamation'. A campaign of vilification against the newspaper and the journalism programme was conducted in some academic quarters. A demand was made to reveal the newspaper's sources to identify who had leaked information from the University Council. However, the public response to the publication of the stories was overwhelmingly favourable.

In the next issue (26 April 1996), Uni Tavur published an editorial exposing the pressure on the paper and defending its decision to publish the stories in the public interest. The university administration remained silent. An account in Pacific Journalism Review said:

By publishing information about the Dr Rali affair, the newspaper Uni Tavur defied suppression and brought a hushed up affair into the public arena, exposing a double standard on ethical behaviour in Papua New Guinea's leading national university. And by making public the pressure on it from the administration, the paper thwarted attempts to muzzle its freedom to report and interpret on behalf of the public. (Robie, 1998, p. 124) 
However, less than three years later the university closed the journalism programme in spite of a struggle by students and staff for resources and support. The programme was reinstated a year later after the then vice-chancellor left for another post in Dubai. Among sporadic editions of the paper that continued to be published, Uni Tavur produced a special edition on 30 July 2001 marking 'Black Tuesday' - the night four people were shot dead, three of them students, during protests against World Bank structural adjustment policies. Several student journalists later gave testimony before a commission of inquiry set up to probe the shootings. One of those students, Wanita Wakus, wrote in a Uni Tavur article headed 'I couldn't stop crying':

The sound of gunshots woke me from my deep sleep. I could also hear the footsteps of people running along the exposed corridors of my dormitory. I opened the door, curious to know exactly what was going on, only to hear someone somewhere in the shadows of the trees yelling at girls to get in and shut their doors. The sound of the gunshots seemed to be getting louder, so I assumed the gunmen were coming closer...

[She fell asleep to the sound of the gunfire].

I woke up again to the screams and gunshots but this time the sun was up ... Walking towards where the group of ladies stood, I saw that the gunmen were none other than the law enforcement officers, the police...

In their hands were the instruments of death. (Wakus, 2001)

Wakus demonstrated both the value of student journalists bearing witness to civil strife and human rights violations, and also the insecurity of campus life at Waigani. A tradition of independent student journalism established 26 years earler was still alive. The mantle of crusading student media was also taken up by the Divine Word University training newspaper, Liklik Diwai, named by using the Tok Pisin words for 'small' and 'tree', or the little newspaper, and Diwai is also a moniker for Divine Word. The newspaper focused many reports on human rights, social justice and development issues.

\section{Wansolwara (Fiji)}

The University of the South Pacific is a regional university with 12 member countries with main campuses in Suva, Port Vila and Apia. ${ }^{1}$ The first journalism course established at USP was a Certificate in Journalism programme (Robie, 2008b, p. 241). It was founded by New Zealander Dr Murray 
Masterton with support from the Commonwealth Fund for Technical Cooperation (CFTC) in 1987, coinciding with Sitiveni Rabuka's military coups d'état. After a successful start, this course eventually wound down in 1991 at the conclusion of a funding cycle. Situated within the then Department of Literature and Language at USP, a completely separate journalism degree course was established in the same department with post-coup French government aid. François Turmel, a specialist radio journalist who had spent many years based in London with the BBC World Service, took early retirement and took up appointment as the senior lecturer and founder of the course. A Papua New Guinea-born Australian colleague, Philip Cass, appointed in 1995, encouraged the creation of the Wansolwara newspaper at USP because there was 'no real outlet for journalism students' work' (Cass cited in Robie, 2004, p. 179). The name Wansolwara — 'one sea' — is also derived from Tok Pisin. 'Wansolwara' expresses the idea that 'all of us who are born or live in the Pacific are bound together by the ocean' (p. 180).

Five of the first editions of Wansolwara featured a distinctive vertical blue reverse masthead for the title on the left side of the front page while the early issues relied on voluntary work by founding editor Stanley Simpson and his student team. The newspaper was not actually funded by the university. But when I arrived at USP in 1998 from the University of PNG to head the journalism studies programme, the department integrated the newspaper into a formal course assessment structure and set up an advertising regime to recover printing and production costs. New Zealand television journalist Ingrid Leary similarly revitalised the broadcast components of the programme.

Wansolwara has arguably been the most successful economic model for a training newspaper in the South Pacific region because it has been able to self-fund publication for 15 years and consolidate its publishing structure. The newspaper has also published concurrently with its sister publication Wansolwara Online at Pacific Journalism Online (www.usp.ac.fj/journ/) and has won a string of awards (Pearson, 2001; Robie 2004). The newspaper has provided strong coverage of environmental issues, development strategies, human rights and social justice, but coverage of the George Speight attempted coup in May 2000 was one of the highlights of the newspaper's history.

\section{The Fiji student internet coup}

Within days of the Speight coup, the students' website and newspaper had created its own international niche market. In a sense, this was an 'internet 


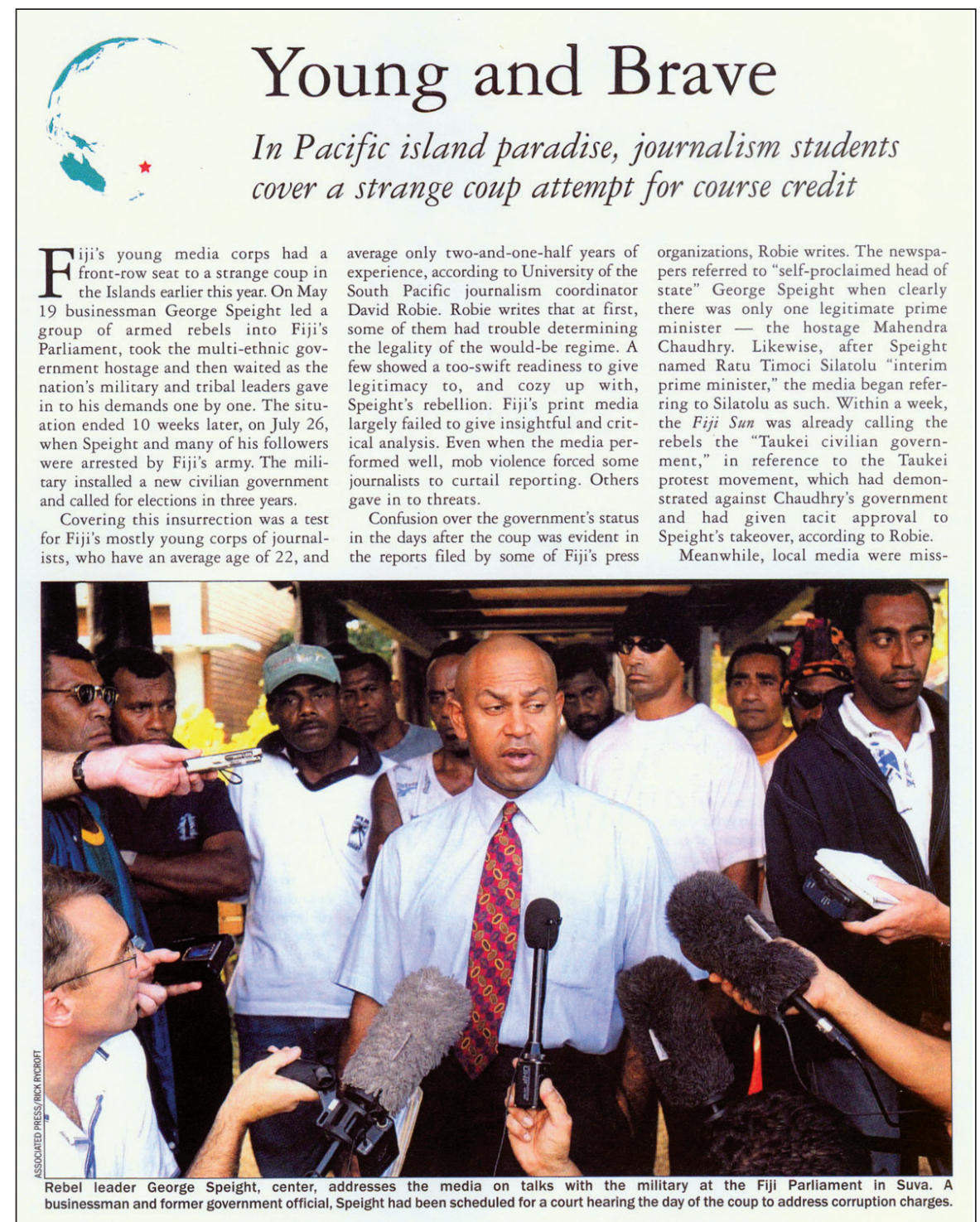

Figure1: IPI Global Journalist, 3rd quarter, 2000, pp. 26-29.

coup', and the students were a vital part of it. And the plaudits were fullsome: 'Young and brave,' said The Global Journalist. 'In a Pacific island paradise, journalism students cover a strange coup attempt for course credits' 
(Ransom, 2000). 'From trainees to professionals. And all it took was a coup,' said the Commonwealth Press Union News (Gounder, August, p. 7). 'Some of the best reporting has come from USP's journalism program ... it was a goldmine of information until it was shut down by the university ... "for security reasons",' wrote New Zealand's City Voice (Rose, 2000)

Although the USP programme was ill-equipped logistically for such sustained daily reportage, it at least had a well-established, two-year-old website in the formative days of online media, Pacific Journalism Online, and a training newspaper, Wansolwara, already in place. It also normally had access to a student FM radio station on campus, Radio Pasifik, but university authorities closed this immediately after the coup.

\section{The beginning}

On Friday, 19 May 2000, almost to the day of the first military coup in the Fiji Islands in 1987, George Speight, a kailoma (mixed race) and bankrupt businessman, tore off his balaclava to reveal his identity after seizing Parliament and the elected government at gunpoint. Within minutes of the news of the hostage taking being flashed on Radio Fiji news on that day's $11 \mathrm{am}$ bulletin - scooped by one of our final-year students on attachment-Professor Subramani came into my office and said: 'There's been another coup'. I was sceptical. Although a coup had been rumoured as being imminent for sometime, I just could not believe it.

After quick phone calls to confirm the facts, sketchy as they were at that stage, I met senior student editors to decide what should be done. At that stage, it was felt the crisis would be over in a few days and we decided to go all out to cover the events - but with a campus perspective. Three months later the students were still covering the crisis (Cass, 2002; Robie, 2001b).

The journalism programme already had a team of reporters at a protest march in downtown Suva that morning (which later erupted into rioting); the news editors set up our radio and television monitors; reporters were dispatched to Parliament (the rear of the university grounds is close to the chamber); the television class was cancelled and a crew sent downtown to Suva where they filmed footage of the riots and arson in the capital. As reporters returned with their stories and digital images, we posted hourly updates on Pacific Journalism Online.

By the time martial law was declared ten days later, on May 29, the student team had posted 109 stories, dozens of soundbites and scores of digital 
photographs. But for the first day, the students stumbled through the hours, in some cases overcome with shock and the trauma over what was unfolding. One talented 20-year-old student was so traumatised that he could not write about what he saw. He went home shaking. However, he recovered by the next day and took a leading role in the coverage for the next three months, finally winning an award for his coup efforts.

On Saturday morning, the students carried on with the coverage but were already facing logistical problems. It was the weekend and not all journalism students were aware that the team was covering events. And the university was about to close and send its 5,000 students home. A small core group managed to see through the weekend.

On Monday morning, May 22, three shifts were organised among the student reporters and editors to cope with the curfew - morning and afternoon shifts, and an overnighter comprising students who actually lived on campus. Sometimes reporters slept in the newsroom. I personally worked from about 7 am until curfew time daily.

At one stage, a group of the students worked 36 hours in one hop, barricaded in the newsroom, to complete the editorial production of a special coup edition of Wansolwara. Although I had a curfew pass, and some of our senior students also had passes, the USP team was handicapped by its lack of logistics. The university was not geared for this sort of journalistic activity and the students had no vehicle-taxis were very unreliable. To add to the frustration, a senior administrator frequently passed the newsroom muttering loudly that journalism students were a threat to the university: 'What will happen if George comes after us?' she complained.

Student online editor Christine Gounder, now a journalist with Radio New Zealand, later produced a masters thesis on the Speight attempted coup and the so-called Stockholm syndrome (Gounder, 2006). She wrote about the putsch at the time as part of an article in the CPU News titled 'From trainees to professionals. And all it took was a coup' (CPU News, 2000):

Student journalists chose to be on the job. But it hasn't been easy. They survived threats, bureaucratic attempts to gag their website and newspaper, and a shutdown of the university to deliver the news.

Grabbing the opportunity to hone their skills, the young journalists didn't waste any time rushing to be on the spot at Parliament on May 19 and the looting and arson sites around the capital, Suva (Gounder, 2000). 
Another student, Tamani Nair, was on internship with the Fiji Broadcasting Corporation at the time of the coup and wrote about his experience (Nair, 2000):

Fiji's third coup could not have come at a better time for student journalists - especially those on attachment. It was a baptism by fire for us.

May 19 was the day it all started. I was fortunate enough to be part of the team that broke the news of the coup.

Radio Fiji records every parliamentary session in the newsroom itself and this saves reporters the torture of going to Parliament and sitting there all day.

We were having our morning tea and joking about parliamentarians - especially the Opposition with their funny comments they made while interjecting.

Deputy Prime Minister Dr Tupeni Baba was speaking at the time. Then we heard somebody yelling and telling the people to remain seated in Parliament and gunshots were fired.

Everybody in the newsroom was shocked. We left everything and moved closer to the radio - and then the lines were cut.

Samisoni Pareti and Sandhya Narayan instantly volunteered to go down to Parliament. I begged the editor, Vasiti Waqa, to let me join the team.

She said 'yes' immediately and told me of the danger which at that moment was the least of my concerns.

On the way to Parliament, Pareti kept saying: 'Oh, not a coup, not again!' And that got me frightened and excited at the same time.

The speed at which we were travelling to Parliament was not funny at all.

Samisoni had reported on the last coup when it had happened in 1987 and it felt like déja $v u$ for him.

The coup took place at 10.35 am and we were outside Parliament by $10.45 \mathrm{am}$. We were greeted by a gunman at the entrance who told us to 'piss off'.

So Pareti reversed the car into a road leading into the cassava patch and we filed our stories for the 11 am news. The timing was perfect.

I believe that we had the upper hand since we recorded parliamentary proceedings. The other journalists were too busy covering the protest march [in Suva] that day and it would have been a shame if we had not broken the news.

When the police arrived at the scene a little after 11am- together with the other media organisations - we were stuck in the middle of 
Battery Road. This was between the gates and the road block erected by the police.

This got the other journalists irritated since they wanted to be in the 'exclusive spot' also.

I look like an Indian and this worked against me whenever I tried to get into Parliament. However, my name, Tamani (which is Fijian) always managed to save the day.

Even rebel leader George Speight who was in the middle of one of his anti-Indian speeches looked at me and said: 'I hope you don't mind'.

And when he was told I was a 'half-caste' like him, he quickly said, 'You know how I feel and what I mean?'

I wanted to say, 'No! You bald-headed freak' but had to keep quiet.

Customary obligations are frequently a burden on Pacific political reporters. Barely starting as a journalist, Nair had already faced the pressures of traditional loyalties. During the Speight coup many journalists were unable to function 'objectively' under the crisis pressures (Moala, 2001, p. 127).

\section{The shutdown}

On Sunday, May 29, hours after a mob attacked Fiji Television and cut transmission for almost 48 hours, the university authorities closed the USP journalism website without explanation, fearing a similar raid on the sprawling Laucala campus (Cass, 2002; Gounder, 2000; Gurdayal, 2000). Undaunted, the students were offered an alternative site hosted by the Department of Social Communication and Journalism at the University of Technology, Sydney, and carried on publishing from the next day (www.acij.uts.edu.au/ archives/index.html). Australian Centre for Independent Journalism director Associate Professor Chris Nash at UTS said: 'The suggestion that journalism staff and students, and indeed any academics, might somehow desist from reporting, commenting and publishing on the current situation is akin to suggesting that doctors and nurses should turn their backs on wounded people in a conflict. It's unconscionable.' (Nash, 2000).

Alison Ofotalau, a young Solomon Islander who had been a former Wansolwara editor, said it was an unfortunate decision by the university since Pacific Journalism Online was one of only three Fiji websites which were reporting internationally with primary source material on the coup: 'It was a great opportunity for us ... and we are lucky to be reporting on a major world event.' Ofotalau compiled a transcript of the controversial Fiji TV Close-Up 
programme, which was claimed to have sparked the attack on the station (Robie, 2000a). The transcript was reposted widely on websites internationally and republished from USP by news agencies. Ironically, it was the last item posted on the USP Journalism website before Pacific Journalism Online was itself shut down.

At a meeting three days after the website closure, requested by the Journalism Programme with the Vice-Chancellor, senior university officials said they wanted 'self-censorship' and for the regular journalism training newspaper Wansolwara to be 'postponed'. When told that Wansolwara had already gone to press, the authorities wanted distribution of the paper stopped and for the paper to be inspected with a view to removing articles. This was refused by the programme staff.

An American graphics designer, Mara Fulmer, who had worked with the Media Centre at USP in the mid-1990s, independently hosted the students' gagged newspaper Wansolwara Online at her Looking Glass website in the US (www.lookinglassdesign.com/wansolwara/wansol.html). Fulmer said: 'I consider it an honour and privilege to do this for freedom of the press. The students have worked so hard on this. They have truly earned their journo stripes' (Noted, September, 2000).

A series of protest letters to the university administration from groups and organisations as diverse as Reporters Sans Frontières in Paris (Ménard, 2000), the Commonwealth Journalists' Association, the NZ Journalism Education Association, Queensland University's Journalism Department, PEN New Zealand and the Committee to Protect Journalists in New York followed. (Robie, 2000). The RSF general secretary, Robert Ménard, wrote to USP vice-chancellor Ali'imuamua Esekia Solofa on 9 June 2000:

Reporters Sans Frontières respectfully asks you to allow Pacific Journalism Online to be reopen[ed] and guarantee that journalists and students can work freely as long as they comply with the law. RSF considers that gagging a website that merely publishes news, and in a professional manner, is a violation of press freedom, Finally, RSF asks you to ensure that [the] newspaper Wansolwara can publish freely. (Ménard, 2000)

Murray Burt, president of the Commonwealth Journalists Association, wrote from Canada: 'I beg you to legitimise the voice of your student 
media. Demonstrate that a free press is critical to democracy and the only hope for saving it' (Burt, 2000). Professor John Henningham, then head of the journalism department at the University of Queensland, wrote: 'Suspension of a news and information-based website is equivalent to closing down a newspaper or television station, and clearly breaches the most fundamental of press freedoms to which all journalists (and academics) are pledged' (Henningham, 2000). The New York-based Committee to Protect Journalists protested about the website closure as part of a two-page statement condemning 'violence against journalists in Fiji' (CPJ, 2000). The CPJ had documented several cases of journalists being detained, assaulted and threatened: 'In one case, a cameraman was shot in the arm; in another incident, soldiers ransacked a local TV station.'

Solofa ignored all the international letters of protest. Instead, I was sent a letter of 'reprimand' - after Wansolwara had been distributed in defiance of the attempt to ban it. He said:

The decision I had taken to close down the Journalism Programme website was a straight-forward decision based entirely on one consideration: the safety and security of the property of the university and of the lives of the people engaged in it...

Let me make an important observation which should cover the criticisms you and others have raised over the closure of the website...

The USP Journalism Programme is not a media agency, neither is it a news/information outlet. The USP Journalism Programme is an education and training facility for future journalists and others who need journalism knowledge and skills in their work... The current closure of the Journalism website has clearly illustrated that our students do not need it to publicise or publish their pieces if that is what their true intention is (Solofa, 2000).

\section{The comeback}

Solofa's letter was leaked from his office to Islands Business magazine, which published it in full in the 'Whispers' column without any contextual or balancing information (Whispers, 2000). Three senior academic staff immediately protested and the president of the USP Staff Association, Dr Biman Prasad, called for Solofa's letter to be withdrawn, saying it was 'unjustified' and condemning 'self-censorship'. Prasad added: 'Academic freedom is always fundamental to the survival and operation of a university, even more 
so when there is a crisis and threats to academic freedom' (Prasad, 2000a). Prasad later described the incident in a paper about the 'crisis of conscience' for USP academic staff when addressing the annual conference of the New Zealand Association of University Staff (NZAUS) in Wellington:

The staff association was vigilant and took a firm stand on issues that we felt were designed to promote self-censorship. For example, soon after the May 19 coup, the university administration in panic unilaterally decided to close the journalism programme website. The journalism students were provided with a fabulous opportunity to practise skills in the real life situation what they were learning in theory. Their reporting on the crisis was appreciated around the world.

The administration's drastic move to shut the website down was rather regrettable from the point of view of both staff and students of journalism. The Association of USP Staff protested vigorously against the closure and it was allowed to continue. (Prasad, 2000b)

On June 28, the website was allowed to reopen (to enable students to access its teaching resources and Online Classroom), on condition no further news was posted about the Fiji coup. Almost a month later, on July 25, the 40-strong academic staff of the School of Humanities' Board of Studies passed an unanimous resolution condemning the administration over the shutdown of the website. Two letters dealing with the political crisis and the role of the university were later forwarded formally to the Academic Committee. One of the important justifications that the academics gave was that the existence of the journalism website provided important information for their security. The letter defending the website, signed by the acting Head of School, Dr Desma Hughes, said:

We believe [the closure of the journalism website on May 29] was unsound pedagogically...

It has been stated that the purpose of the journalism programme's productions and publications are as training grounds for prospective journalists from around the region. We consider that the journalism website provided outstanding and excellent training for the journalism students in that it involved reporting and commenting on real issues.

The situation that evolved during the time of the coup can hardly be simulated for the purposes of teaching. 
The coup gave our students an ideal opportunity to practise their journalism skills under the supervision of one of the school's professional staff members, especially in the area of investigative journalism. We therefore find it difficult to understand the rationale behind the decision to suspend the website that deprived our students. (Hughes, 2000)

The Board's letter said that being informed was a crucial element of personal security. While the university's security needs were understood, the journalism programme's 'unique contribution' to the distribution of reliable and objective news and commentary to Pacific people and the world should have been carefully considered.

But while the academics wrangled over the issues of security versus academic freedom, the student journalists carried on with the job. They continued to feed stories and digital pictures on the Fiji and Solomon Islands crises by email to the ACIJ website until the end of August, when the USP Journalism website editorial policy was resolved - and unchanged. News coverage returned to normal at the Laucala campus.

\section{The aftermath}

The USP Journalism awards night on November 24 was exemplary. Four students were honoured with prizes for their reportage during the coup and a group of second-year students showed their mini-documentary about the closure of the website, Frontline Reporters: Coup Coverage by Student Journalists. Tamani Nair, a reporter who scooped the takeover of Parliament for Radio Fiji won the Best Student Radio Reporter Prize; Matelita Ragogo, who was briefly held captive in the Parliamentary press gallery by the rebels, won the Best In-depth Story Prize for a profile on George Speight; Reggie Dutt won the Best Editor Prize for editing Wansolwara and Pacific Journalism Online during the coup; and Joe Yaya won the Most Promising First-Year Student Prize for his pictures of masked gunmen and other images that were published around the world.

But a remarkable point about the awards event was a diplomatic row unleashed by the chief guest, then New Zealand High Commissioner Tia Barrett, who took a modest swipe at the slowness of bringing the coup perpetrators to justice. He also made an important statement about Indigenous issues and journalism which riled the military-installed regime: 
What is difficult to accept in this dialogue on Indigenous rights is the underlying assumption that those rights are pre-eminent over other more fundamental human rights. This just cannot be so, not in today's world ... Nowhere is it written in any holy scripture that because you are Indigenous you have first rights over others in their daily rights. You should be respected and highly regarded as an indigenous person, but respect is earned, not obtained on demand. (Barrett, 2000)

In the end, said Barrett, information would make the difference in the process of cultural change for Pacific Islanders in the face of globalisation to improve people's lives. This was where the journalist played an important role. Barrett appealed to the coup-surviving graduates to always bear in mind the needs of their people and their thirst for knowledge.

A footnote to the affair came a week later in the Journalism Education Association (JEA) awards in December 2000. Known as the Ossies, after the late Australian foreign correspondent Osmar S. White and funded by his estate, USP students won two of the major awards and were highly commended in four others for their reporting of the Speight attempted coup. Pacific Journalism Online website, 'devoted to daily coverage of the coup', won the Dr Charles Stuart Prize for best student publication in any medium while the Pacific students' newspaper Wansolwara was awarded a highly commended in the same category. Pacific Journalism Online also won the award for best regular publication (cited by Pearson, 2001). Category judge, deputy editor Mike van Niekerk, of The Age Online, said the students working on the publication 'rose to the challenge of providing high quality reports of a dramatic international news event on their doorstep':

They did so in challenging circumstances and by providing these reports on the internet they were one of the few sources of information at critical times of the events taking place. As such, the quality of the writing is of a high standard for students. Taken as a body of work, it is very impressive. (Cited by Pearson, 2001)

Ironically, after a standing ovation at the JEA awards, a conference paper that I presented on December 6 about media coverage of the Speight coup entitled 'Coup coup land: The press and putsch in Fiji', stirred an international controversy, particularly in Fiji (Robie, 2000b). Five days later, a PINA Nius Online email report misrepresenting the paper was distributed to 
Pacific newspapers. A campaign of bitter personal attacks against the author followed on the JEANet and Penang Commonwealth editors email list-servers over the next two weeks. A two-page article published in Pacific magazine presented the furore as a 12-round boxing match fought out on the internet, 'heavily slanted in favour of the Fiji Times and PINA' (Pacific, 2001). The anonymous author wrote:

The magazine cited a formal complaint by the newspaper's expatriate publisher and editor-in-chief to the University of the South Pacific, alleging 'manufactured evidence to establish an erroneous conclusion'. This was rejected by the university. The magazine did not interview the author or seek a copy of the paper, nor did it canvas vews of other media commentators supporting the analysis. (Robie, 2001a, p. 157)

Rejecting the Fiji Times criticisms and protesting against Pacific magazine's misrepresentations, Association of University of the South Pacific Staff (AUSPS) spokesperson associate professor Scott MacWilliam said in a letter to the editor: 'AUSPS is concerned that, while the Fiji Times and other news organisations purport to support the freedom to express opinions, such opinions are only acceptable if they sustain the same organisations' views of themselves' (MacWilliam, 2001).

\section{The legacy for Fiji journalism}

A decade on, the author has contacted several former students and staff involved in the coup coverage at the time to gauge their reflections and how they consider the experience has impacted on them today. Matelita Ragogo was one of three journalists reporting in the parliamentary press gallery on the morning of 19 May 2000 when Speight's gunmen walked in. A senior journalist on the Fiji Times at the time, she recently accepted a Commonwealth Secretariat scholarship to study in Britain a decade on from that fateful day. Immediately before moving to Brighton, she was studying for a Postgraduate Diploma in Pacific Studies at the University of the South Pacific. As an independent journalist, her reporting had included being a correspondent for Radio New Zealand International (RNZI) and contributing to local and regional outlets such as The Fiji Times, Pacnews, Islands Business and Pacific magazine. She recalled: 
I was in Parliament when [George Speight] walked in with his crew. They were a dishevelled bunch, obviously disorganised. No one reacted, I think the initial reaction was more of amusement - in the press gallery it was. At least until the first gun shot when we realised it was more sinister than what met the eye.

It was interesting to watch the reactions of the MPs-you noticed who did not place their phones in the waste basket that was taken around to the members. [Prime Minister] Mahendra Chaudhry and Tupeni Baba [one of two deputies] and the rest of the male members of government were dragged out of their seats and kicked behind the knee to force them down - it was a sad process to watch.

What irony to watch someone who everyone in Traps [a wellknown Suva bar] knew was a [failed businessman] issuing orders and talking about Indigenous rights to governance. It was definitely the first time I saw him in a sulu; I knew he could not speak Fijian fluently, his Australian accent did not help!

A plainclothes soldier had by now positioned himself behind us, with his M16. Josephine was crying. John and I could just stare at the horrible way things were unfolding downstairs. And then we heard the noise. The [demonstrators] who had marched through town had reached Parliament.

Watching the winding dark line of humans marching up to Parliament sent chills down my spine - the mass finally made me confront what was happening: A repeat of 1987, except I was actually witnessing it this time.

Everything after that - the first press conference, those who felt they could swing Speight's plans off, a whole company of soldiers marching in; civilians with guns-was a blur for me. You could cut the atmosphere with a knife- there was real hatred in that place.

My worst memory is hearing them, those who had taken over a government, having their devotion and singing hymns in rooms several feet away from where the hostages were kept.

This was not Christianity, never mind the caring, hospitable lot Fijians were known as (M. Ragogo, email interview with author, 22 April 2010).

Ragogo subsequently reported for international media, always with a strong commitment to democracy and against armed political interventions. The Speight coup had made a deep impression on her and the combinaton of student journalism at Wansolwara, industry experience and legal studies gave 
her an edge with her media freedom work. Asked about the closure of the USP journalism website when martial law was declared, Ragogo recalled:

I did hear about the journalism website shutting down (by now theyjournalism students - were part of the media corps that staked out the Parliament complex) and felt that as a university, USP had definitely failed its students: Obviously, it did not want to risk attacks from the rebels nor risk its funding from whichever group would make up the new government.

The willingness of another university to publish the students' stories was admirable but there were also discussions making the rounds about its motivations. By now, our parachute journalists had truly pitched their tents and the students' contribution may have been giving them a run for their money. As well, it represented another source of information they had to check. (Ragogo, ibid.)

What are your reflections about independent student journalism and publications at journalism schools?

As a former editor of Wansolwara, [I found that] student journalism and publications at journalism schools are essential for such opportunities. Dependent on the dynamics of the student newsroom and how team-oriented the students are, such newspapers offer an introduction to the ethics and professionalism the students will have to apply in the real world. To already have that discipline can mean a much easier integration to the real [media] world. (Ragogo, ibid.)

Has your journalism experience been a different formative one from what you might have experienced without this training and development?

You come out stronger as a believer in democratic principles, especially when you see how members of the government were humiliated, when you catch glimpses of the hostages walking around their tiny rooms, when you see young men, teenagers, pretend to be soldiers in morning drills, when you see how desecrated what was once a Parliament, when you hear of rebels shooting dead a policeman and trashing a newsroom, when you witness an atmosphere of hate and distrust ... I could go on.

The changes I saw in some senior journalists, though, caused some disillusionment: No matter what happens, there will always be people who benefit and if your newsroom bosses are of one politic, and you another, then obviously, frustrations will occur.

118 PACIFIC JOURNALISM REVIEW 16 (2) 2010 
I left the [Fiji Times] two years later, for very different reasons, but knowing that wherever I worked, I would remain objective and never ever fabricate things just for a good story. And I have no doubt that I will always oppose the forceful removal of democratic governance, however it is justified.

Shailendra Singh was editor of The Review news magazine at the time of the Speight putsch and has since become divisional head of journalism at the University of the South Pacific. He has been responsible for development of Wansolwara in the post-millennium years. He found the Speight period and the closure of the USP journalism website a 'defining moment' for the regional university. The campus administration was challenged over freedom of speech and academic freedom issues.

At the time, people [in Fiji] were still learning about the internet. The coup brought home the power of this new medium. The internet had made censorship virtually impossible. The Australian Centre for Independent Journalism stood in solidarity with USP journalism over media freedom issues. It showed how important international networks are when media freedom comes under threat and news is being suppressed. (S. Singh, email interview with author, 21 April 2010).

Singh believes strongly campus-based training newspapers such as Wansolwara 'play an important role in training students in real world journalism':

They get to experience what is meant by deadlines and some of the other daily pressures of being a journalist - such as attempts by people to intimidate them, or to influence news. They make mistakes and learn from them. Such publications are an alternative source of news. They are not beholden to advertisers, neither do they face the kind of commercial pressures that mainstream news organisations do. Student publications can be bolder, they can take risks and they can experiment to try out things that commercial media may not be able to. (Singh, ibid.)

Reggie Dutt, then editor of Wansolwara and also on the editorial team of Pacific Journalism Online, is now on a postgraduate programme at Bond University, Queensland, after having worked at Fiji Television and other media, and as a researcher for the Fiji Human Rights Commission. 
At the time, reporting on the May 2000 coup was an exciting challenge for me. At no point did I stop to think about not reporting, or continuing to go to university every day to work on the PJO, while the semester was put on hold by the university. Only when the university closed down the website, did I think the situation through. Even then, I was against the university's decision to shut us down and felt it was unfair to prevent us from learning 'on-the-job' from this unique opportunity.

As it happened, a number of avenues opened up for the PJO to be published on mirror sites, like the one created at ACIJ. Personally, I was disappointed with the university, but was happy that we had the mirror sites to publish our stories on. Would I do the same all over again? Without a moment's hesitation. (R. Dutt, email interview with author, 27 April 2010).

Christine Gounder, then working for the Fiji Daily Post and also editing online at Pacific Journalism Online, is now a Radio New Zealand journalist and has filed a steady stream of Fiji-based stories in recent months. She recalls:

I feel privileged to have been part of the student team that took the opportunity to put to use the skills learnt in the school newsroom into practice. It was both a nervous and an exciting time and something we can be proud of for our lifetime. I still remember the day we received a threatening call asking us to shut down Pacific Journalism Online as we were one of the few telling the world what was happening in Fiji. That phone call made us aware of how important our job was and made us want to work even harder.

We were disappointed when the USP vice-chancellor at the time, Esekia Solofa, decided that $P J O$ would be temporarily closed for our safety and for the safety of USP. This wouldn't have happened if we [had been] an independent online news service or newspaper, but we had to comply because we didn't have the independence we thought we should have had. We were delighted when the ACIJ offered to be a mirror for our website, and so the work went on.

I believe serious journalism students will learn a lot more from taking on the type of responsibility that independent publications present. The exposure to the pressures of producing the publication on time, having quality news, feature and sports stories, as well as layout and advertising to pay for the publication, gives students an appreciation of the processes in a wholesome manner. With Wansolwara and PJO, I experienced real-life journalism which helped put the journalism 
profession in perspective for me (S. Gounder, email interview with author, 27 April 2010).

Noora Ali was an international student from the Maldives studying journalism for three years at the time. She is now the director of Project Maldives Pvt Ltd and provides media consultancy, research and training in documentary film making. Before taking up the appointment in mid-2009, she held the position of Permanent Secretary of the Ministry of Tourism, Arts and Culture in the Maldives and was responsible mainly for the media and arts component of the ministry's work:

I remember trying to go to Parliament to cover stories, managing to get in, being mistaken for an Indo-Fijian, and writing stories for Wansolwara. Sad for Fiji were those days, but for a journalism student it was really a time to step up from being a student to the real world of journalism.

I am very proud to have been a part of the Wansolwara team who covered the Fiji 2000 coup. Proud to have worked with David who showed us how real journalists carry themselves and the triumph in bringing news to the people and the world in difficult and trying times. (N. Ali, emailed interview with author, 27 April 2010)

Noora Ali says that the coup coverage experience was one of the most profound experiences she has ever had and it provided guidance for her career future:

The USP journalism days shaped me. They also provided an atmosphere of free thinking on media reforms that needed to take place in my own country. [This] certainly laid the foundation for the work I did ahead in my media career, mostly in the area of policy formulation. (Ibid.)

At the time, Patrick Craddock was senior/media producer at the USP Media Centre and was teaching broadcast journalism. His previous media background had been with Radio New Zealand where he worked for more than 20 years as a producer of Morning Report, on the Insight weekly documentary programme, on Radio New Zealand International and as manager of the Continuing Education Unit. During the attempted coup, Craddock was in charge of a broadcast audio studio at USP. After establishing the small Radio Pacific FM station at the university several years 
before the coup, he began experimenting with internet broadcasting in spite of the narrow broadband width then available at the university. He recalls:

For at least 48 hours, maybe longer, there was little news going out of Fiji to the outside world media. David knew this and so did I. I began recording audio from local Suva radio stations and did this task on an hourly basis. The news was quickly edited and sent by the internet to media agencies in New Zealand, Australia and Britain.

My memory of the time is of recording audio from the public and private radio stations for around 16 hours a day and sending audio packets over the internet. By around the third day after the coup, the world media had landed in force in Suva and was well established. I kept recording, editing and dispatching audio news for several weeks. (P. Craddock, email interview with author, 11 May 2010)

Craddock regards the establishment of Wansolwara as an important part of journalism education at USP: 'It encouraged students to write, see their work published and to receive comments back from the published exposure' (Craddock, 2010).

Over the years I have seen numerous editions. It still serves a genuine training ground with real news. That is its strength. When I left [Fiji] in 2007 , more than 3000 copies were being printed and students wrote news and feature stories. Year Three journalism students researched and wrote full-page articles, the first year students did shorter ones. Advertising was well established with the aim of making the newspaper pay its way. Students learned to walk the streets, knock on doors, smile, and talk and get money for advertisements for Wansolwara. (Ibid.)

\section{Conclusion}

Given the socio-political realities and demographics of both Fiji and Papua New Guinea, it has never been easy being a journalist. In Fiji, both the leading ethnic groups - indigenous and Indo-Fijian - 'feel equally aggrieved' (Singh \& Prasad, 2008, p. 3). Fijians believe they are marginalised in business and the professions and fear losing political control in their homeland. However, Indo-Fijians believe they have been denied their fair share of political power, and they are discriminated against in education and government jobs. Also, voting in Fiji is along ethnicity lines, and for decades many politicians have played on these prejudices in electorates. 
In Papua New Guinea, complex rivalries between ethnic and cultural groups also divide the nation and have serious impacts on the effectiveness of the news media.

In this context, the student press and broadcasters in the Pacific universities need to be proactive in their coverage and philosophy as news media. They need to defend the freedom of the press and freedom of expression in the traditions of an independent Fourth Estate while also helping Pacific nations forge a common vision shared by all its citizens. This is not an easy challenge because while Wansolwara and other student publications are exempt from registration under Fiji's new Media Industry Development Decree 2010, they are still subject to the same harsh penalties for breaches. Self-censorship pressures mean that editors would 'think twice' about publishing any criticism of Fiji state policies or players. Thus today it is far more difficult to match the free press benchmarks set by the student press in earlier years. However, in late 2009 Wansolwara struck a partnership with the Fiji Sun to publish the newspaper as an independent 16-page tabloid liftout and continues to win awards for its social justice issue investigations and professionalism (Fiji Sun boosts Wansolwara's readership with hot press deal, 2009).

A shared view of many of the students reflecting on what they learned during the putsch is that student journalism was in many respects more independent than the mainstream commercial media driven by profit. Some thought that 'the sheer experience was worth a three-year journalism degree'. A novel idea and popular perhaps but not one that was realistic. While reporting the coup was certainly cathartic, and led to some pedagogical changes, such as including critical 'military studies' with journalism school workshops alongside peacekeeping soldiers on leave from Timor-Leste duties in the Suva barracks - to better understand the military psyche - the experience proved a unique one-off case. When the next coup came with Bainimarama seizing power in December 2006, students were already on vacation and the regional campus was virtually empty. Nevertheless, like the Sandline mercenary crisis in Papua New Guinea, the Speight coup experience helped propel them into the real world and tested their ability to hold their nerve and provide ethical guidelines as young student journalists: 'I don't think any of us blinked and it gave us all a huge amount of confidence. It gave our team members a selfbelief that they could report on the big stage, asking the right questions and writing good stories' (Dutt, 2010). 


\section{Note}

1. Cook Islands, Fiji, Kiribati, Marshall Islands, Nauru, Niue, Samoa, Solomon Islands, Tokelau, Tonga, Tuvalu and Vanuatu.

\section{References}

Barrett, T. (2000). Journalism and indigenous issues. Address by NZ High Commissioner at the USP Journalism Awards, Suva, November 24. Retrieved on 28 February 2001, from www.usp.ac.fj/journ/docs/news/usp29awards00.html (no longer retrievable at this url)

Burt, M. (2000). Student media voice deserves university's support. [Open letter to the USP Vice-Chancellor], June 19.

Cass, P. (2002). Baptism of fire: How journalism students from the University of the South Pacific covered the Speight putsch and its aftermath. The Round Table: The Commonwealth Journal of International Affairs, 91(366), 559-574

CPJ (Committee to Protect Journalists). (2000, July 19). CPJ condemns violence against journalists in Fiji. [Media release].

CPUNews (2000). From trainees to professionals. And all it took was a coup. London: Commonwealth Press Union, August, p 7. Retrieved on 28 February 2001, from www.usp.ac.fj/journ/docs/news/cpunews.html (no longer retrievable on this url)

Fiji Sun boosts Wansolwara's readership with hot press deal. (2009). Pacific Scoop. Retrieved on 8 September 2010, from http://pacific.scoop.co.nz/2009/09/fiji-sunboosts-wansolwaras-readership-with-hot-press-deal/

Gounder, C. (2006). The Fiji 2000 coup: A media analysis. Unpublished MCS thesis, School of Communication Studies, Auckland University of Technology.

Gounder, C. (2000, August). Taking a coup in your stride. CPU News. London: Commonwealth Press Union, p 7.

Gurdayal, M. (2000, June 21). University shuts down website. Fiji Daily Post.

Henningham, J. (2000). Letter to the USP Vice-Chancellor, June 16.

Hughes, D. (2000). Letter to USP Academic Committee, September 11.

Johnston, C. (1996, January 18-24). Security crisis at PNG uni. Campus Review, 6(1), 1.

MacWilliam, S. (2001, April). Getting the facts straight - and more. [Letter to the editor]. Pacific Magazine, p. 6.

Ménard, R. (2000). Letter by the Reporters Sans Frontières (RSF) general-secretary to University of the South Pacific Vice-Chancellor, June 9.

Miise, M. (1996a, February 23). Academic suspended over office raid. Uni Tavur, p. 1. Miise, M. (1996b, February 23). The tragedy of Janet Kisau. Uni Tavur, p. 5.

Miise, M. (1996c, March 22). Council votes to sack Rali. Uni Tavur, p. 1.

Nair, T. (2000, June 16). A baptism of fire. [ACIJ/USP] Fiji crisis archive. Retrieved on 25 April 2010, from www.acij.uts.edu.au/archives/fiji_coup/0616baptismoffire. html

Nash, C. (2000). Letter by the Australian Centre for Independent Journalism (ACIJ) director to the USP Vice-Chancellor, June 13. 
Noted. (2000, September). Media ban defied. Wellington: NZ Journalists Training Organisation (NZJTO). Retrieved on 25 April 2010, from Pacific Media Watch database www.pacmediawatch.aut.ac.nz

Pacific Magazine (2001, February). New Zealand academic stirs up Pacific storm, pp. 42-43.

Pearson, M. (2001, February). Ossies recognise promising talent of the future. PANPA Bulletin, p. 19.

Prasad, B. (2000a). Letter to USP Vice-Chancellor, July 27.

Prasad, B. (2000b). Crisis of conscience. Keynote address to the annual conference of the NZ Association of University Staff. Wellington, December 4-5. Retrieved on 22 April 2010, from www.asiapac.org.fj/cafepacific/resources/aspac/fijiprasad.html

Ragogo, M. (2000, June 14). The day of the parliamentary gunmen. ACIJ/USP Fiji crisis archive. Retrieved on 25 April 2010, from www.acij.uts.edu.au/archives/ fiji_coup/0614dayofgunmen.html

Ransom, S. (2000). Young and brave: In Pacific island paradise, journalism students cover a strange coup attempt for course credit. IPI Global Journalist, Third Quarter. 6(3), 26-28.

Robie, D. (2008a). Freedom of the gatekeepers: A free media study of NZ and Fijiself-regulation or state intervention? In Fijian Studies: A Journal of Contemporary Fiji, 6(1\&2), 55-86.

Robie, D. (2008b). An independent student press: Three case studies from Fiji, Papua New Guinea and New Zealand. In Papoutsaki, E., \& Harris, U. S. (Eds.), South Pacific Islands communication: Regional perspectives, local issues (pp. 235-253). Singapore: Asian Media Information and Communication Centre, and Auckland: Pacific Media Centre.

Robie, D. (2004). Mekim Nius: South Pacific media, politics and education. Suva: University of the South Pacific Book Centre.

Robie, D. (2002). Cyberspace news on campus: The South Pacific experience. AsiaPacific MediaEducator, No 12/13, 203-162.

Robie, D. (2001a), Coup coup land: The press and the putsch in Fiji. Asia Pacific Media Educator, No. 10, Jan-June 2001.pp. 148-162. Retrieved on 25 April 2010, from http://kauri.aut.ac.nz:8080/dspace/handle/123456789/16

Robie, D. (2001a), Coup coup land: The press and the putsch in Fiji. Asia Pacific Media Educator, No. 10, Jan-June 2001. pp. 148-162. Retrieved on 25 April 2010, from http://kauri.aut.ac.nz:8080/dspace/handle/123456789/16

Robie, D. (2001b). Frontline reporters: A students' internet coup. Pacific Journalism Review, 7(1), 47-56.

Robie, D. (2000a). Coup coup land: The press and the putsch in Fiji. Paper presented at the Journalism Education Association (JEA) conference, Mooloolaba, Queensland, December 5-8. Retrieved on 23 April 2010, from www.asiapac.org.fj/cafepacific/ resources/aspac/fiji3148a.html 


\section{MEDIA FREEDOM IN OCEANIA}

Robie, D. (2000b). Complaint to the Fiji Media Council No. 112: USP journalism coordinator David Robie vs Islands Business adjudication date: 27 June 2001 and an independent critique of the adjudication by media lawyer Richard Naidu, of Munro Leys, and related papers. Available at BRN: 988349 USP Library. 31 July 2000.

Robie, D. (1998). The Rali affair: A case study for a free press. Pacific Journalism Review, 5(1), 114-124.

Rose, J. (2000, June 8). Fiji: The internet coup. City Voice (p. 8). Wellington: New Zealand.

Singh, S., \& Prasad, B. (2008). Coups, media and democracy in Fiji. In Fijian Studies: A Journal of Contemporary Fiji, 6 (1\&2), 1-8.

Solofa, E. (2000), Letter to the USP Journalism Coordinator, June 22.

Stevenson, R. L. (2004). Freedom of the press around the world. In Arnold S. de Beer \& John C. Merrill, Global journalism: Topical issues and media systems (pp. 66-83). Boston: Pearson Education Inc.

The National (1996, February 23). News media cover-up alleged [Letter to the editor republished in Uni Tavur].

Uni Tavur. (1996, April 26). [Editorial]. A free student press and its responsibility. p. 4. Waibauru, J. (1994, July 22). Frog's heads, old ashtrays and politics. Uni Tavur, pp. $10-11$.

Wakus, W. (2001). 'I couldn't stop crying.' Uni Tavur, 30 July 2001; republished in Pacific Journalism Review, 7(1), 127-128.

Whispers. (2000, July). A dear Mr Robie letter. Islands Business, p. 13.

\section{Websites}

Australian Centre for Independent Journalism (ACIJ) archive of University of the South Pacific student press Fiji coup stories from 29 May 2000 (restored 22 April 2010): www.acij.uts.edu.au/archives/fiji_coup/index.html

Looking Glass Design mirror website (in the US, hosting a special online copy of the Wansolwara coup edition): www.lookinglassdesign.com/wansolwara/wansol.html University of the South Pacific: www.usp.ac.fj

Dr David Robie was head of journalism at the University of Papua New Guinea and then University of the South Pacific from 1993-2002. He is now director of the Pacific Media Centre. A version of this article was presented as one of the University of Queensland World Press Freedom Day Lectures at St Lucia, Brisbane, on 29 April 2010.

david.robie@aut.ac.nz 